\title{
スパッタリングプロセス中の不純物制御による 機能性磁性薄膜の微細組織制御*
}

\author{
高橋 研*1.角田 匡清*1・D.D. ジャヤプラウィラ*1
}

（受理2000年 7 月 5 日，掲載決定2000年 9 月 2 日）

Realization of Desirable Microstructure in Functional Magnetic

Thin Films by Controlling the Impurities in Sputtering Process

\author{
Migaku TAKAHASHI ${ }^{* 1}$, Masakiyo TSUNODA*1 and David D. DJAYAPRAWIRA*1 \\ Department of Electronic Engineering, Graduate School of Engineering, Tohoku University, \\ Aoba-yama 05, Sendai 980-8579
}

(Received July 5, 2000, Accepted September 2, 2000)

\section{1. はじめに}

磁気ハードディスク装置の高密度化・高性能化は, パ ーソナルコンピュータの加速的な普及, ならびに, 昨今 に括けるハードディスク搭載の録画装置等, 情報家電製 品の開発を促し, 高度情報化社会進展の大きな原動力の 一つとなっている、ハードディスク装置の記録密度は, 驚嘆すべき勢いで向上し，最近では年率100\%程度のス ピードで伸び続けている．このような超高密度磁気記録 に対応するために，薄膜記録媒体ならびに再生用磁気一 ッドに用いられるGMR（巨大磁気抵抗効果）薄膜に は, その性能の向上が, 材料物性上極限に近いところま で要求されてきている.これら機能性磁性薄膜の特性 は, 結晶粒界の構造や極薄磁性層間での磁気的相互作 用, ならびに薄膜表面や異種金属間の積層界面での電子 散乱現象等により大きく左右されるため, 性能向上を実 現するためには, 薄膜微細組織の高度制御技術が,必要不 可欠である. 図1に示すよらに，磁気記録媒体ならびに GMR 薄膜は, 単一材料による成膜ではなく非常に薄い 異なる材質からなる多数の層の薄膜の組み合わせ構造を とり，一般にスパッタリング法により作製される．この

\footnotetext{
* 平成12年 3 月 29 日 春季第 47 回応用物理学関係連合講演会で講演

*1 東北大学大学院工学研究科電子工学専攻 (宁980-8579 仙台市青苯区 荒巻字青葉05)
}

ため，薄膜が作製されるベースとなる真空の質と磁気的 特性との相関性を, 薄膜微細組織の変化を通じて理解す ることが, 極めて重要である. 本解説では, その典型例 として, 図1に示した 3 種類の磁性薄膜（1)長手媒体記 録層用 CoCrPt 系合金膜, (2)再生へッド GMR 薄膜用 $\mathrm{Co} / \mathrm{Cu} / \mathrm{Co}$ 多層膜, (3)同 $\mathrm{Ni}-\mathrm{Fe} / \mathrm{Mn}-\mathrm{Ir}$ 積層膜) の場合 について，具体的に説明する.

薄膜媒体（ハードディスク，磁気テープ等）に括いて 必要とされる，媒体の高保磁力化打よび低ノイズ化を実 現するためには, 図2(a)に示すように, 記録層中の各 磁性結晶粒が非磁性粒界層で包久こまれ，磁気的孤立性 が高められた組織を維持しながら, 更なる磁性結晶粒の 微細化を通して, 磁気クラスターの微細化を図ることが 肝要である ${ }^{1)}$ また，巨大磁気抵抗 (GMR) 効果を利 用した磁気再生へッドに批いては, 再生感度の向上なら びに再生ノイズの低減を図るために, 図 2(b) に示すよ 与に, 強磁性層/非磁性層積層界面のマクロな平坦化と 原子レベルでのミキシング状態の実現 2 , ならびに強磁 性層/反強磁性層積層界面での清浄界面の確保3), さら に欠陥・結晶粒界等の低減によるスピン非依存性散乱の 減少と熱安定性の確保が必要となる.

このよらな機能性磁性薄膜の性能向上を実現するため の薄膜微細組織制御の新たな一手法として, 筆者らはこ れまでに, 超清浄雾囲気下でのスパッタリングプロセス 


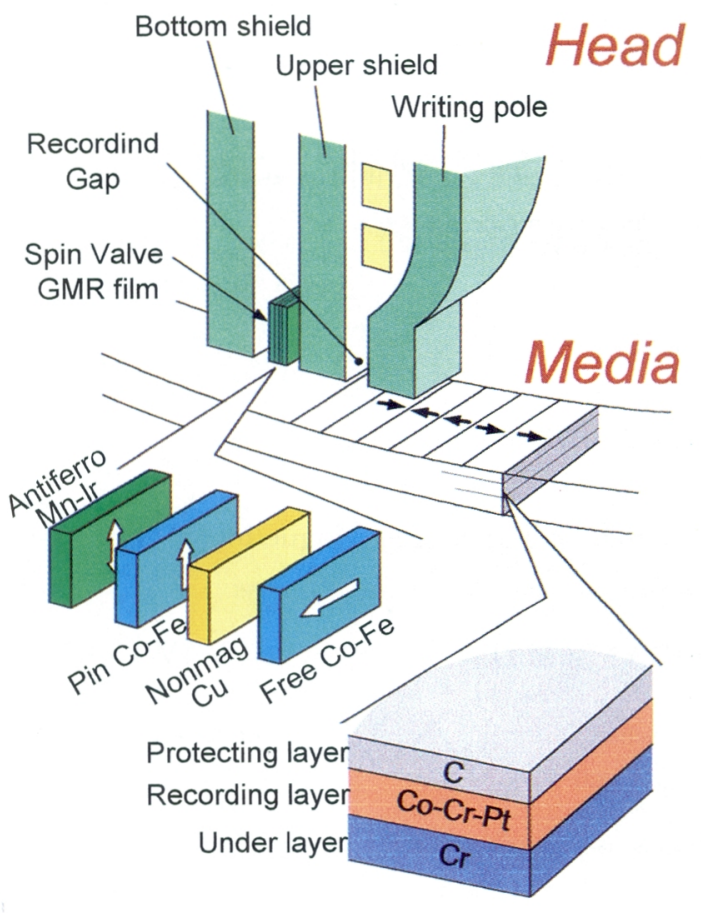

図１ハードディスクに用いられる機能性磁性薄膜 （積層構造，材料は一例）

を提案してきている4). 本解説では, 超清浄プロセスを 基本インフラとし，そのプロセス不純物に対する制御性 の高さを利用した新なな成膜プロセスを導入することに よって, 機能性磁性薄膜に求められる理想的な微細組織 が実現可能となることを述べる，具体的には，超高真空 のバックグラウンドの上に, 各薄膜層形成毎に適切な不 純物制御を行らことによって, 磁気特性の優れた薄膜形 成が可能となった。CoCrPt 系合金記録媒体の場合に は，小分散・微細結晶粒子を成長させるために，その下 地としてのWCr シード作製に执いて，不純物ガスの吸 脱着制御が望ましい. Co/Cu/Coの GMR 膜では，大 きな磁気抵抗変化比（MR 比）得るために, 成膜中の 酸素あるいは水を $10^{-6} \sim 10^{-5} \mathrm{~Pa} レ$ レ゙ル適切な分圧に 設定するのが望ましい. $\mathrm{Ni}-\mathrm{Fe} / \mathrm{Mn}-\mathrm{Ir} の$ バイアス磁界 発生膜では，大きな交換磁気異方性を得るために，10-9 $\mathrm{Pa} レ$ ベルの成膜のバックグラウンドが望ましい，以下 にはこれらについて具体的に述べる。

\section{2. 薄膜磁気記録媒体}

長手磁気記録媒体のノイズを低減するためには, 磁気 的に孤立した強磁性結晶粒子の粒径微細化が有効であ る1,5)。しかしながら, 粒径の微細化に伴う一ヶの結晶 (a)

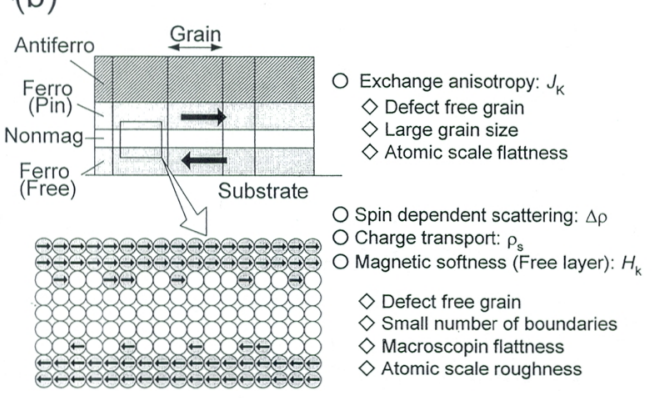

図 2 長手記録媒体 (a)ならびにスピンバルブ GMR 薄膜 (b) としての理想的な組織の概略 図

粒の磁気異方性エネルギーの低下は, 熱磁気緩和現象に よる磁化情報の消失を引き起こす。そのため, 平均粒径 の微細化と同時に粒径分布を狭鋭化して，熱磁気緩和時 間が短い，過度に微細化した粒子を混在させないことが 重要となる。従来, 粒径微細化の手法として, 磁性層の 下地となる Cr 層の膜厚の低減が行われてきたが，それ に伴う結晶配向性の低下と媒体保磁力の低下が問題とな っていた ${ }^{6)}$. 本項ではこれら問題を解決するための新し いプロセス技術として, 高融点金属シード層と不純物吸 脱着を利用した薄膜組織制御技術7,8) とついて述べる. 本手法の基本的なコンセプトは, 極薄膜厚の高融点金属 シード層を組織制御膜として用い, 均一分散した島状組 織を有するシード層上に下地 Cr 合金層/磁性合金層を 形成しょらとするものであり，基板上への不純物吸脱着 によって, 島状組織の核生成密度を変化させることを意 図している。

成膜は, 超清浄プロセス対応 DC マグネトロンスパ ッタ装置7)で行い, 超平滑 $\mathrm{NiP} / \mathrm{Al}$ 基板上に, WCr 合金 シード層, Cr 合金下地層, CoCrPt 系合金磁性層の順に 積層した。プロセスガスには，ユースポイントに打ける 不純物濃度が 1 ppb 以下の超高純度 Ar ガス (UC-Ar) を用いた7) . 基板上に吸着している不純物は，主に大気 中から真空チャンバー内に, 基板に吸着したまま持ら込 まれたものであり，UC-Arを用いた逆スパッタ法（ド ライェッチング）により除去した. 図 3 に示すように, シード層形成とドライェッチングの順序を変化させ, 吸 着不純物が媒体微細組織に及湆す影響について検討し 


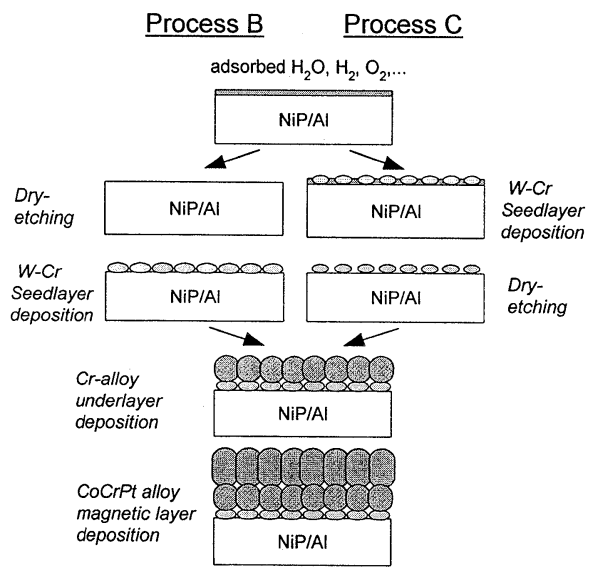

図 3 基板吸着不純物と島状シード層を利用した薄 膜媒体の作製手順の模式図

た。

図 4 に, シード層厚を0（Media A）ならびに0.5 nm (Media B，C) とし，(1)シード層，(2)下地層ならびに(3) 磁性層の組成をそれぞれ(1) $\mathrm{W}_{54} \mathrm{Cr}_{46}$, (2) $\mathrm{Cr}$, (3) $\mathrm{Co}_{64} \mathrm{Cr}_{15}$ $\mathrm{Ta}_{3.5} \mathrm{Ni}_{12.5} \mathrm{Pt}_{5}$ として作製した薄膜媒体の透過電子顕微鏡 （TEM）像を示寸，図 5 には，図 4 に示した TEM 像の 解析によって求めた磁性結晶粒径の分布を示す．比較の 為に市販の $6 \mathrm{~Gb} / \mathrm{in}^{2}$ 対応媒体の粒径分布をあわせて示 した. Media B, C は，それぞれ図3に拈ける成膜プロ セス $\mathrm{B}, \mathrm{C}$ に対応し，シード層形成とドライエッチング の順序が異なる。

シード層を形成していない Media A の平均結晶粒径 $10.8 \mathrm{~nm}$ に比較してシード層を形成した Media Bならび に C の平均結晶粒径は, $9.7 \mathrm{~nm}$ ならびに $7.6 \mathrm{~nm}$ と小さ くなっていることが判る. 特に, Media C の結晶粒径 の減少は著しく, 粒径の分散も極めて小さい. Media A に対して Media B，Cの粒径が減少したことは， $W_{54}$ $\mathrm{Cr}_{46}$ シード層の形成が薄膜媒体の微細組織制御に有効 であることを示し, さらに, Media B と C との差異は, 島状のシード層の基板上での分散状態が，吸着不純物の 存在によって影響を受けることを示し, 不純物の存在に よって島状のシード層の核形成密度が増大したことを意 味している。

図 6 には，プロセス $\mathrm{C}$ を用いて，(1)シード層，(2)下 地層ならびに(3)磁性層組成をそれぞれ(1) $\mathrm{W}_{50} \mathrm{Cr}_{50}$, (2) $\mathrm{Cr}_{90} \mathrm{Mo}_{10}$, (3) $\mathrm{Co}_{66} \mathrm{Cr}_{24} \mathrm{Pt}_{8} \mathrm{~B}_{2}$ として, シード層厚を変化 させて作製した薄膜媒体の磁気特性 $\left(H_{\mathrm{k}}^{\text {grain }}, G D_{\text {act }} / G D\right)$ ならびに媒体ノイズの指標として，41.7 kfci で測定した 孤立信号出力と $500 \mathrm{kfci}$ で測定した媒体ノイズの比（Signal to Noise ratio: $S / N)$ を示す ${ }^{8)}$. シード層厚 0 は, プ
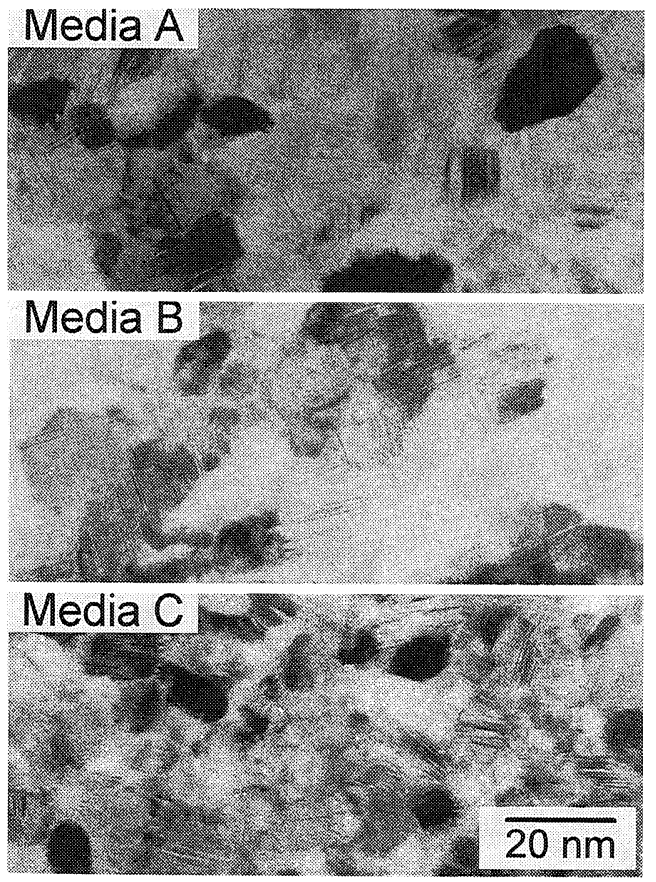

図 $4 \mathrm{Cr} / \mathrm{CoCrTaNiPt}$ 媒体の TEM 像. WCr シー ド層厚 0 (Media A), $0.5 \mathrm{~nm}$ (Media B, C).

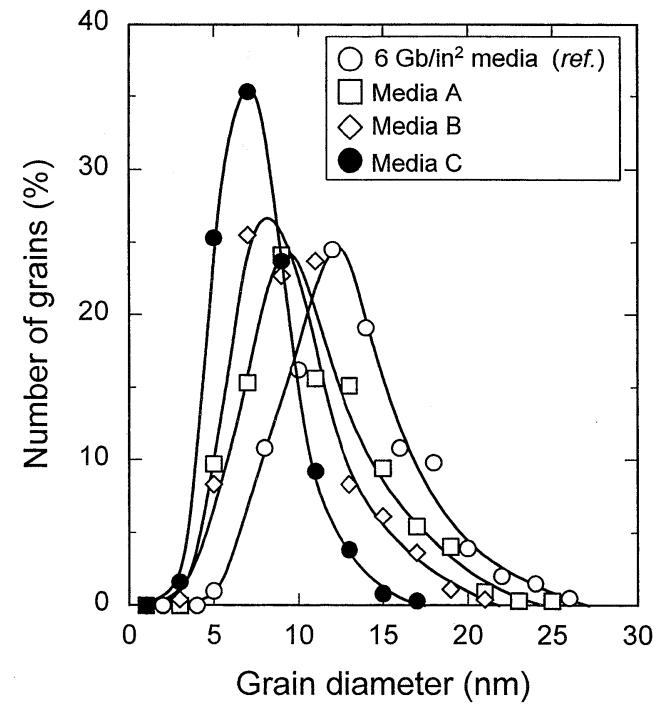

図 5 TEM 像から求めた $\mathrm{Cr} / \mathrm{CoCrTaNiPt}$ 媒体の 結晶粒径分布.

ロセス A に相当する. $H_{\mathrm{k}}^{\text {grain }}$ は, 磁性結晶粒の真性的な 異方性磁界であり, この值の低下は磁性結晶粒内部の欠 陥増加等, 結晶性の低下を意味する4). $G D_{\text {act }} / G D$ は, 熱磁気緩和過程における活性化粒径と物理粒径との比で 


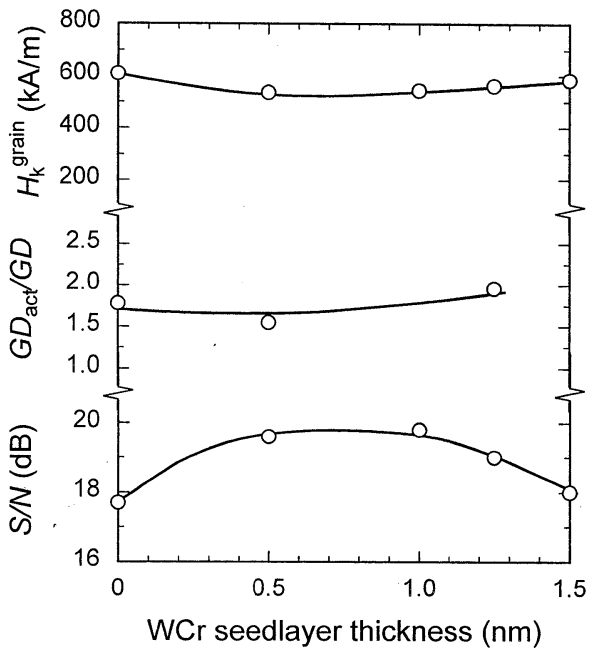

図 6 プロセス C で作製した $\mathrm{CrMo} / \mathrm{CoCrPtB}$ 媒体 の異方性磁界 $\left(H_{\mathrm{k}}^{\text {grain }}\right)$, 規格化活性化粒径 $\left(G D_{\text {act }} / G D\right)$ ，执よび媒体ノイズ $(S / N)$ の WCr シード層厚依存性.

あり,この值の增大は, 結晶粒の磁気的孤立性の低下, すなわち結晶粒界に批りる非磁性 $\mathrm{Cr}$ 偏析層の不完全形 成を意味する ${ }^{9}$.

$H_{\mathrm{k}}^{\text {grain }}$ ならびに $G D_{\mathrm{act}} / G D$ は, シード層厚に対してほ ぼ一定の值を示し、シード層形成による結晶粒径の微細 化に際して, 磁性粒の結晶性ならびに結晶粒界の非磁性 偏析層が，良く保たれていることを示している。一方 $S / N$ 比には, シード層厚 0 の場合に比較して, シード層 厚 $0.5 \mathrm{~nm} \sim 1.0 \mathrm{~nm}$ の範囲では，拈よそ $2 \mathrm{~dB}$ の向上が見 られ, 磁性粒径の微細化によって媒体ノイズの低減が実 現できたことを示している.

大気中から成膜装置に導入された $\mathrm{NiP} / \mathrm{Al}$ 基板の表面 には, 水分を始め, 酸素, 炭化水素などの不純物が吸着 していると考学られる。このような不純物は，Cr 合金 下地層ならびに磁性層内に拡散して粒界非磁性偏析層の 形成を妨げ，媒体の磁気特性を劣化させるため, 従来排 除されてきた ${ }^{10)}$ 。しかしながら，プロセス $\mathrm{C}$ 亿示すよ らに, 例亲ばンード層の組織制御のみにピンポイント的 にこの様な不純物ガスを用いることで極めて有用なプロ セス制御が可能となることが判った.

\section{3. 磁気再生へッド用薄膜}

スピンバルブ型 GMR 薄膜 ${ }^{11}$ は基本的に 4 層から成 り, 非磁性層 ( $\mathrm{Cu}$ 層) を挟んで形成された 2 枚の強磁 性層の一方に, 反強磁性層が積層されている(図 2b). 反強磁性層が積層されていない側の強磁性層 (フリー層) は記録信号の検出を担い，媒体からの漏孔磁束により磁

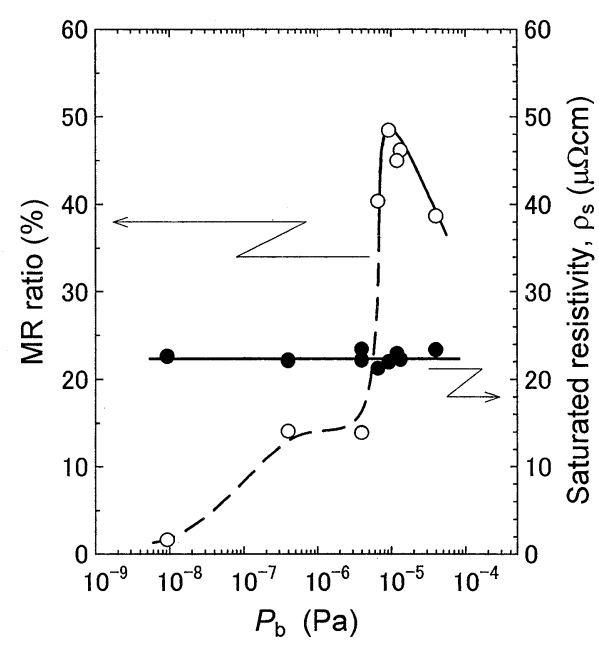

図 $7 \mathrm{Co} / \mathrm{Cu}$ 多層膜の磁気抵抗变化率 (MR 比) と飽和抵抗率 $\left(\rho_{\mathrm{s}}\right)$ の成膜前チャンバー圧力 $\left(P_{\mathrm{b}}\right)$ 依存性.

化回転を起こす，また，反強磁性層を積層した強磁性層 （ピン層）の磁化は, 常に一方向に固定され，フリ一層 の磁化反転に際して, フリ一層とピン層の磁化方向に相 対的な角度差を生ぜしめる. 両層の磁化の相対角度の変 化は, 伝導電子のスピン依存散乱を生じ2)，スピンバル ブ GMR 薄膜素子の電気抵抗の変化として記録信号の 再生が行われる12)。この上らに，スピンバルブ GMR 薄膜を機能させる為には, 磁化の相対角度変化に上る強 磁性層/非磁性層界面に括ける伝導電子のスピン依存散 乱と, ピン層の磁化を一方向に固定するための強磁性層 /反強磁性層界面に括汀る交換磁気異方性 ${ }^{13}$ が，二つの 重要な物理的因子である。そこで，1) Co/ Cu 多層膜 ${ }^{14)}$ を例にとり, 成膜雾囲気中の不純物量を変化させた雾囲 気で多層膜を作製し, 不純物が薄膜の微細組織变化を介 して, 強磁性層/非磁性層界面に括けるスピン依存散乱 に及ぼす影響を検討してみだ5)。さらに，2）強磁性層/ 反強磁性層積層膜の交換磁気異方性に及洼す成膜雾囲気 中の残留不純物の影響を, 積層膜の微細構造, 特に反強 磁性粒子の結晶粒径の観点から検討を行った.

成膜には，極高真空対応マルチスパッタ装置16)を用 い，UC-Arをプロセスガスとして用いた，成膜時の $\mathrm{Ar}$ ガス圧は特に断らない限り拉よそ0.1 Paである. 成 膜䨌囲気中の残留不純物濃度は, UC-Ar 導入前のチャ ンバーの圧力 $\left(P_{\mathrm{b}}\right)$ を大気解放後の排気時間を調整する ことによって行った．基板には熱酸化膜付 $\mathrm{Si}$ ウェ八を 用いた。 


\section{$3.1 \mathrm{Co} / \mathrm{Cu}$ 多層膜の $\mathrm{GMR}$ 効果に及ぼす不純物の影} 響

図 7 に, Sub./(Co $1 \mathrm{~nm} / \mathrm{Cu} 0.9 \sim 1 \mathrm{~nm})_{30} / \mathrm{Cu} 2 \mathrm{~nm}$ の 積層構造を有する多層膜の磁気抵抗変化率（MR 比） と, 飽和抵抗率 $\left(\rho_{\mathrm{s}}\right)$ を成膜前チャンバー圧力 $\left(P_{\mathrm{b}}\right)$ の 関数として示す. 測定時の最大印加磁界は $1 \mathrm{MA} / \mathrm{m}$ と し, 印加方向は, 膜面内で測定電流と直交する方向とし た.

MR 比は, 零印加磁界に拈ける抵抗率 $\left(\rho_{0}\right)$ を用い て， $\left(\rho_{0}-\rho_{\mathrm{s}}\right) / \rho_{\mathrm{s}}$ と定義した． $\rho_{\mathrm{s}}$ は，最大印加磁界下で の抵抗率であり，このとき各 Co 層の磁化は，印加磁界 方向へ飽和していることから，スピンに依存しない電子 散乱の大きさの指標となる。一方, 磁気抵抗変化 $\left(\rho_{0}-\right.$ $\left.\rho_{\mathrm{s}} \equiv \Delta \rho\right)$ は，零印加磁界に拈忷る隣接磁性層磁化の配 列状態によって変化し, 完全な反平行配列が実現してい るときに最大となる2)。したがって，MR 比は，多層膜 中の強磁性層/非磁性層界面に打村る伝導電子のスピン 依存散乱と, スピン非依存散乱の大きさの割合を示し, スピンバルブ型磁気再生ヘッドの再生感度を増すために は，その増大が極めて重要な要因となる。

図7に打いて，P居を $4 \times 10^{-5} \mathrm{~Pa}$ から $1 \times 10^{-5} \mathrm{~Pa}$ まで 低下させると，MR 比は $39 \%$ から $48 \%$ まで増大する。 しかし， $P_{\mathrm{b}}$ を $4 \times 10^{-6} \mathrm{~Pa}$ まで下げ，わずかに成膜雲囲 気中の残留不純物ガスを減少させるだけで, MR 比は $14 \%$ まで急激に減少することが判る. 更に $P_{\mathrm{b}}$ を低下さ せ $1 \times 10^{-8} \mathrm{~Pa}$ とすると, GMR 効果はほとんど観測さ れず，MR比は $1 \%$ 程度となる。一方 $\rho_{\mathrm{s}}$ は， $P_{\mathrm{b}}=1 \times$ $10^{-8} \mathrm{~Pa} \sim 4 \times 10^{-5} \mathrm{~Pa}$ の範囲で，汇とんど一定值22 $\mu \Omega \mathrm{cm}$ を示しており, $\mathrm{MR}$ 比の $P_{\mathrm{b}}$ に対する変化が, $\Delta \rho$ 変化によるものであることが判る.

$\Delta \rho$ の減少は，零磁界に扣ける隣接磁性層磁化の反平 行配列の割合が減少していることに対応する。一般に, $\mathrm{Co} / \mathrm{Cu}$ 多層膜の場合, 隣接 Co 層同士には, RKKY 相 互作用もしくは量子井戸効果による磁気的層間相互作用 が, 両層を隔てる非磁性 $(\mathrm{Cu})$ 層厚の関数として減衰 振動的に働き, $d_{\mathrm{Cu}} \sim 0.9 \mathrm{~nm}$ では, 零磁界において隣接 磁性層磁化を反平行に配列させる様に作用する2)，この ことを考慮すると, 図 7 の $1 \times 10^{-5} \mathrm{~Pa}$ 以下の領域に括 ける MR 比 $(\Delta \rho)$ の変化は, 成膜雲囲気中の残留不純 物の低減によって，上記の層間相互作用に反して隣接磁 性層磁化の反平行配列が阻害されたことを意味してい る。

MR 比に影響を及ぼした成膜䨌囲気中の残留不純物 を特定するために，一旦成膜装置を超高真空 $\left(1 \times 10^{-8}\right.$ $\mathrm{Pa}$ 以下）まで排気した後に所定の分圧まで，酸素，水 分, 窒素を導入し, その上で UC-Ar を用いて先と同様

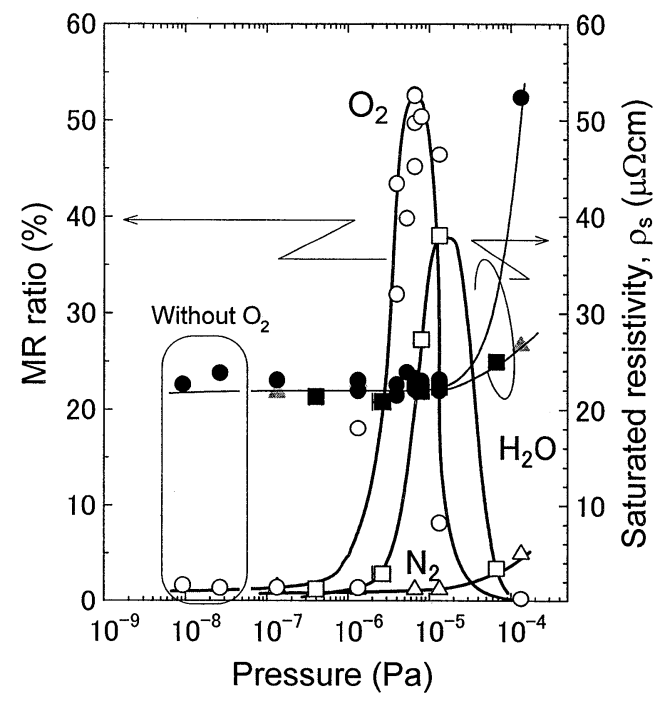

図 8 不純物添加䨌囲気中で作製した $\mathrm{Co} / \mathrm{Cu}$ 多層 膜の磁気抵抗変化率 (MR 比) と飽和抵抗 率 $\left(\rho_{\mathrm{s}}\right)$ の不純物添加分圧依存性.

の膜構成を有する $\mathrm{Co} / \mathrm{Cu}$ 多層膜を作製した ${ }^{17)}$.

図 8 に，作製した多層膜の MR 比ならびに $\rho_{\mathrm{s}}$ の添加 不純物分圧依存性を示す．酸素ガスを添加した場合の MR 比は, $1 \times 10^{-7} \mathrm{~Pa}$ の分圧では $1 \%$ 程度と, 酸素を 添加しない場合とほとんど変わらない，ところが，酸素 分圧 $1 \times 10^{-6} \mathrm{~Pa}$ 以上では, $\mathrm{MR}$ 比が急激に上昇し， $7 \times$ $10^{-6} \mathrm{~Pa}$ では，50\%以上にまで増大する．更に酸素分圧 を増大させると，逆に MR 比は減少し始め, $1 \times 10^{-4}$ $\mathrm{Pa}$ に拎いて, GMR 効果は消失した。すなわち, 酸素 分圧 $1 \times 10^{-6} \mathrm{~Pa} \sim 2 \times 10^{-5} \mathrm{~Pa}$ の非常に狭い範囲でのみ GMR 効果が観測されることが明らかとなった．水分を 添加した場合は，MR 比が観測される分圧範囲が， $3 \times$ $10^{-6} \mathrm{~Pa} \sim 1 \times 10^{-4} \mathrm{~Pa}$ となる以外は, 酸素添加の場合と ほぼ同様の変化を示した．一方で，窒素ガスを添加した 場合の MR 比は， $1 \times 10^{-5} \mathrm{~Pa}$ までの分圧では，不純物 を添加しない場合とほとんど変化がなく，GMR 効果を 示さないことが判った.

以上の結果より, 成膜雲囲気中の残留不純物として, 酸素及び水分が $\mathrm{Co} / \mathrm{Cu}$ 多層膜の GMR 効果に多大な影 響を及ぼしていることが明らかとなった，更に，酸素お よび水分添加の場合の結果を比較すると, MR 比が極 大值を示す添加分圧が，抒抢よそ 2 倍異なっている.こ のことから，多層膜の GMR 効果に影響を及ぼす不純 物因子は，プラズマ中で解離した酸素原子（イオンまた はラジカル）であることが示唆される.

一方, 各不純物ガスを添加した場合の $\rho_{\mathrm{s}}$ の変化は, 


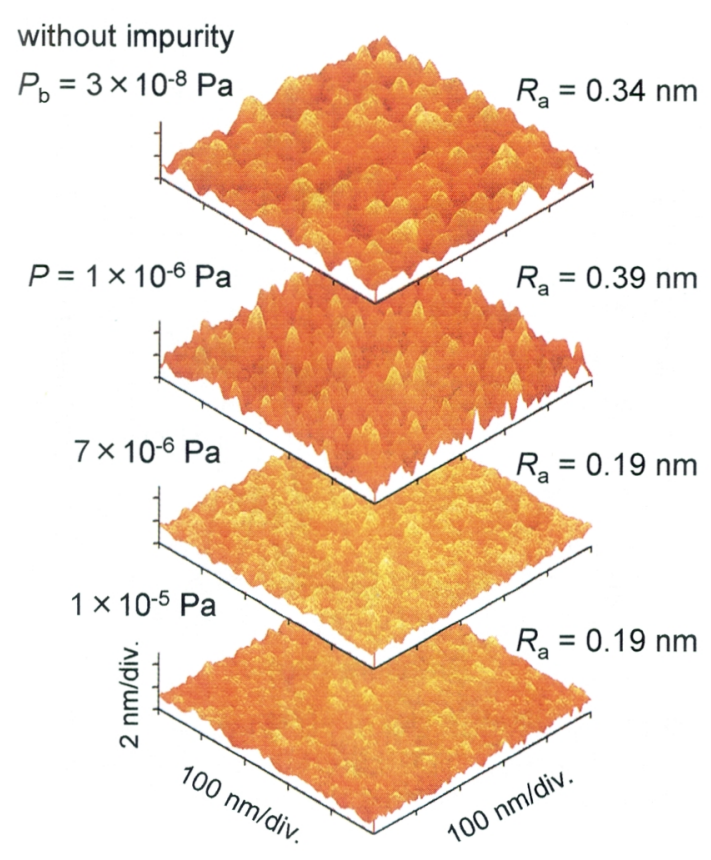

図 9 不純物酸素添加雲聿気中で作製した $\mathrm{Co} / \mathrm{Cu}$ 多層膜の表面の AFM 像と, AFM 像から求 めた表面粗さ $\left(R_{\mathrm{a}}\right) . P$ は添加酸素分圧.

どの不純物に対しても，括よそ $1 \times 10^{-5} \mathrm{~Pa}$ までの分压 では, ほぼ一定值 $22 \mu \Omega \mathrm{cm}$ を示す。しかし， $1 \times 10^{-5}$ $\mathrm{Pa}$ 以上の添加の場合には抵抗率の上昇が見られ，特に 酸素分圧 $1 \times 10^{-4} \mathrm{~Pa}$ では, 2 倍以上の増大が認められ る.このことは, 過剩の不純物添加雾囲気中で作製した $\mathrm{Co} / \mathrm{Cu}$ 多層膜に拈いては, 多層膜の酸化が進行してい ることを意味し, 添加不純物分圧が高い領域での, 分圧 増大に伴ら MR 比の減少は, 多層膜の酸化によるもの と推察される。一方, 酸素ならびに水分添加によって MR 比が極大值を示した分圧以下の範囲においては， $\rho_{\mathrm{s}}$ の変化はほとんどなく，この範囲における添加不純物分 圧の低下に伴 $5 \mathrm{MR}$ の急激な低下が $\Delta \rho$ の变化による ものであり, 先に述べたように, 零印加磁界での隣接磁 性層磁化の反平行配列の割合が低下していることが判 る.このよらな, $\mathrm{Cu}$ 層を通しての磁性層間相互作用に 関係した，隣接磁性層磁化の反平行配列の阻害原因を調 ベるために, 多層膜の積層構造の平坦性を, 表面の AFM 観察によって評価してみた.

図 9 には, 酸素を添加して作製した Co/ Cu 多層膜最 表面の AFM 像を示す. 添加分圧 $(P)$ の増加に伴って, 膜面内の結晶粒径に相当する凹凸の径が減少する。ま た, 表面粗さ $R_{\mathrm{a}}$ \& $P$ の増大に伴って減少し, MR 比が 極大を示した $P=7 \times 10^{-6} \mathrm{~Pa}$ 以上では, $P=1 \times 10^{-6} \mathrm{~Pa}$

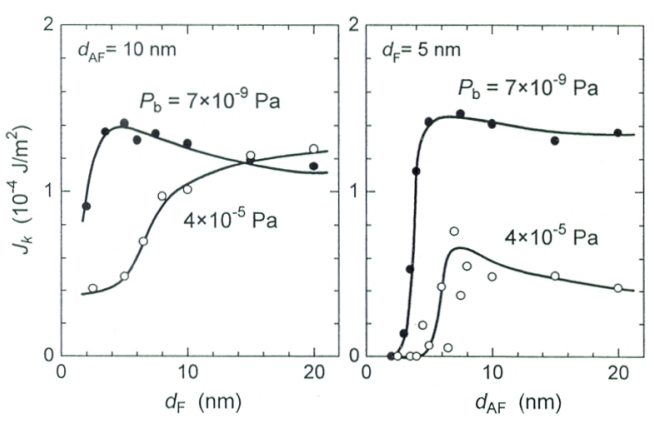

図 $10 \mathrm{Ni}-\mathrm{Fe} / \mathrm{Mn}-\mathrm{Ir}$ 積層膜の一方向異方性定数 $\left(J_{\mathrm{K}}\right)$ の強磁性層厚 $\left(d_{\mathrm{F}}\right)$ ならびに反強磁 性層厚 $\left(d_{\mathrm{AF}}\right)$ 依存性. $P_{\mathrm{b}}$ 怯成膜前チャンバ 一圧力.

の場合に比較して，拉よそ半分となった。このことは, 不純物酸素の存在によって, $\mathrm{Co} / \mathrm{Cu}$ 多層膜の積層構造 の平坦性が向上することを示している。このよらな積層 構造の変化は, 先に考察したよらに, 解離した不純物酸 素原子によって多層膜が部分的に酸化され，その結果と して金属結晶粒子の三次元的成長が抑制されたことに起 因していると考えられる。

次に, 多層膜の積層構造の変化と磁気特性との相関に ついて考光る。多層膜の各層の膜厚は $1 \mathrm{~nm}$ 程度と極め て薄いため, 積層構造の平坦性が劣化した場合, 隣接磁 性層同士の部分的な接触が起こり得る. 磁性層の部分的 接触は, 直接交換相互作用を介して隣接磁性層磁化を平 行配列させる. そら考光ると， $P=7 \times 10^{-6} \mathrm{~Pa}$ 以下の領 域に拈いては, 添加酸素分圧の低下に伴って, 積層膜の 平坦性が劣化し, 磁性層の部分的接触の割合が増加した ために, 磁気抵抗変化 $\Delta \rho$ が減少したものと考觉ると説 明がつく.

以上の例で見たように, 成膜雲囲気中の不純物酸素 は, 金属多層膜の平坦性を向上させるために有効な添加 元素であることが判った。

\section{$3.2 \mathrm{Ni}-\mathrm{Fe} / \mathrm{Mn}-\mathrm{Ir}$ 積層膜の交換磁気異方性に及ぼす} 残留不純物の影響18)

図10に，清浄性の異なる2つの雾井気中で作製した 4 層膜 Sub./Ta $5 \mathrm{~nm} / \mathrm{Ni}_{0.8} \mathrm{Fe}_{0.2} d_{\mathrm{F}} / \mathrm{Mn}_{0.74} \mathrm{Ir}_{0.26} d_{\mathrm{AF}} / \mathrm{Ta} 5 \mathrm{~nm}$ に扣壮る一方向異方性定数, $J_{\mathrm{k}}\left(\equiv M_{\mathrm{s}} d_{\mathrm{F}} H_{\mathrm{ex}}\right)$ の, 強磁性 層厚 $\left(d_{\mathrm{F}}\right)$ 依存性ならびに反強磁性層厚 $\left(d_{\mathrm{AF}}\right)$ 依存性 を示す。飽和磁化 $\left(M_{\mathrm{s}}\right)$ ならびに交換結合磁界（ルー プシフト磁界: $H_{\mathrm{ex}}$ ) は, 振動試料型磁力計 (VSM) で 測定した磁化曲線から求めた。測定は室温で行った。一 万向異方性定数の大ささは交換磁気異方性の強さであ り, これが大きいほど, スピンバルブ膜のピン層磁化を 強固に一方向に固定させることができ, 外乱磁界に対し 


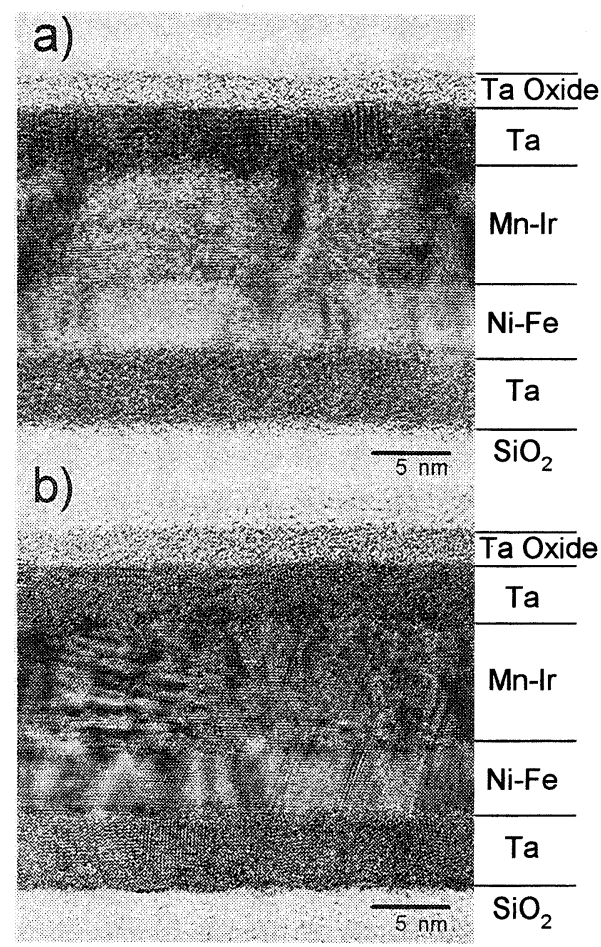

図11成膜前チャンバー圧力 $\left(P_{\mathrm{b}}\right)$ を変化させて 作製した $\mathrm{Ta} / \mathrm{Ni}-\mathrm{Fe} / \mathrm{Mn}-\mathrm{Ir} / \mathrm{Ta}$ 積層膜の断 面 TEM 像. $P_{\mathrm{b}}=7 \times 10^{-9} \mathrm{~Pa} \quad$ (a)， $P_{\mathrm{b}}=4 \times$ $10^{-5} \mathrm{~Pa}(\mathrm{~b})$.

ての耐性を増し, 再生ノイズの低減に対しても重要な要 素の一つである.

成膜前チャンバー圧力 $\left(P_{\mathrm{b}}\right)$ を $7 \times 10^{-9} \mathrm{~Pa}$ ならびに $4 \times 10^{-5} \mathrm{~Pa}$ と変化させることによって, 成膜プロセス 中の不純物濃度は約 2 桁変化する ${ }^{18)}$ 。 また, 四重極質量 分析計を用いて残留ガス分析を行った結果, $P_{\mathrm{b}}=7 \times$ $10^{-9} \mathrm{~Pa}$ に打いては水素が，また， $P_{\mathrm{b}}=4 \times 10^{-5} \mathrm{~Pa}$ にお いては水分が残留ガスの主成分であることが判った ${ }^{19)}$. 二次イオン質量分析計 (SIMS) による分析の結果, 作 製した積層膜中の不純物として, 酸素 $(\mathrm{m} / \mathrm{e}=16)$ の含 有量が， $P_{\mathrm{b}}=4 \times 10^{-5} \mathrm{~Pa}$ で作製した膜では， $P_{\mathrm{b}}=7 \times$ $10^{-9} \mathrm{~Pa}$ で作製した場合のそれに比較して約一桁多いこ とが判った ${ }^{20)}$.

図10において， $P_{\mathrm{b}}=4 \times 10^{-5} \mathrm{~Pa}$ で作製した積層膜に 比較して， $P_{\mathrm{b}}=7 \times 10^{-9} \mathrm{~Pa}$ で作製した積層膜の $J_{\mathrm{k}}$ が， 著しく大きくなっていることが判る．特に，極薄膜厚領 域に拈ける $\mathrm{Ni}-\mathrm{Fe} / \mathrm{Mn}-\mathrm{Ir}$ 積層膜の交換磁気異方性の大 きさは, 成膜雲囲気の清浄化により顕著に増大すること が判る.

図11は, $d_{\mathrm{F}}=5 \mathrm{~nm}, d_{\mathrm{AF}}=10 \mathrm{~nm}$ の 4 層積層膜の断面
TEM 像である. $P_{\mathrm{b}}=7 \times 10^{-9} \mathrm{~Pa}$ で作製した積層膜(a)

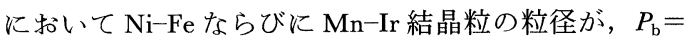
$4 \times 10^{-5} \mathrm{~Pa}$ で作製した積層膜(b)のそれよりも大きいこ とが明らかである。また， $P_{\mathrm{b}}=7 \times 10^{-9} \mathrm{~Pa} て ゙$ 作製した 積層膜では, fcc-(111) 結晶面が $\mathrm{Ni}-\mathrm{Fe}$ 層の初期層から $\mathrm{Mn}-\mathrm{Ir}$ 層の最上部まで, 基板面に平行に積み重なって いることが明瞭に観察される. fcc-(111)結晶面は，優先 配向面であり，薄膜成長に際して，基板とのエピタキシ ャル成長性, 吸着・酸化などの薄膜表面の改質等の付加 的要素が存在しなければ，表面ェネルギーの最も低い fcc-(111)結晶面が基板面に対して配向する．従って，図 11 の結果は, 成膜雾囲気中の残留不純物の排除によっ て，薄膜成長に拈ける核発生サイトが減少する，あるい は基板に到達したスパッタ粒子が不純物によって捕獲さ れることが無くなるために, その面内移動度が増大し， 欠陷が少なく, 且つ膜面内の粒径の大きな結晶粒が形成 されたことを意味している。

図11(b)で見られる様な反強磁性粒子の結晶粒サイズ の低下は，局所的なブロッキング温度の低下を招き，そ の結果として積層膜全体に働く一方向異方性定数を低下 させる ${ }^{21)}$. 従って, 交換磁気異方性を示す強磁性層/反 強磁性層積層膜の場合には，成膜雾囲気中の不純物を排 除することによって，1）膜中に取り込まれる不純物が低 減され，2)反強磁性結晶粒の面内成長が促進され，3) $J_{\mathrm{k}}$ の温度特性が改善される. 以上の総合的な結果として， 室温に打ける積層膜の交換磁気異方性が増大されること が判った.

\section{4. よ め}

機能性磁性薄膜の典型として，ハードディスク装置に 用いられる, 薄膜記録媒体, 強磁性層/非磁性層多層膜, ならびに強磁性層/反強磁性層積層膜について, 成膜雲 囲気中の不純物の存否によって, 結晶粒界や積層界面の 薄膜微細構造は著しく変化することを述べた．このよう な微細構造の変化は, 粒間ならびに層間の磁気相互作用 に影響を与え, 結果として薄膜デバイスの磁気特性その ものを左右する. したがって, 所望の磁気特性を導出す るための理想的な薄膜微細組織を実現するためには，こ れら従来不純物元素としてしか考えられていなかった酸 素などのガス種の積極的利用も，重要なプロセス技術の 一つである．真空チャンバーならびにプロセスガス中に 残留する不純物を徹底的に排除した上で，有用な元素 （ガス種）のみを，任意の時点・箇所に十分に制御して 添加することにより，完全に制御された薄膜作製プロセ スが実現でさる，薄膜の極限までの微細組織制御が要求 される超高密度磁気記録デバイス作製に対して，不純物 
制御を含めた超清浄プロセスは極めて有用である.

\section{〔文献〕}

1）例总ば，高橋 研：応用物理, 68 (1999) 185.

2）例之ば，猪俣浩一郎：応用物理，63（1994） 1198 .

3) K. Uneyama, M. Tsunoda and M. Takahashi: IEEE Trans. Magn., 33 (1997) 3685.

4）例总ば, 高橋 研：応用物理, 65 (1996) 1218.

5) M. Takahashi, A. Kikuchi and S. Kawakita: IEEE Trans. Magn., 33 (1997) 2938.

6）菊地 䀘，中井淳一，河北信也，三ッ谷晴化，島 津武仁, 高橋 研: 日本応用磁気学会学術講演概要 集, 東京, 1995 (日本応用磁気学会, 東京, 1995), 409.

7) S. Yoshimura, D. D. Djayaprawira, T. K. Kong, Y. Masuda, H. Shoji and M. Takahashi: J. Appl. Phys., 87 (2000) 6860

8) M. Takahashi, H. Shoji, D. D. Djayaprawira and S. Yoshimura: IEEE Trans. Magn., 36 (2000), in press.

9) S. Yoshimura, D. D. Djayaprawira, T. K. Kong, Y. Masuda, H. Shoji and M. Takahashi: IEEE Tran. Magn., 36 (2000), in press.

10) S. Kawakita, T. Sakurai, A. Kikuchi, T. Shimatsu and M. Takahashi: J. Magn. Magn. Mater., 155 (1996) 172.
11) B. Dieny, V. S. Sperious, S. S. P. Parkin, B. A. Gurney, D. R. Wilhoit and D. Mauri: Phys. Rev. B, 43 (1991) 1297.

12）例光ば, 中田正文, 山田一彦：固体物理，32 (1997) 242.

13) R. D. Hempstead, S. Krongelb, D. A. Thompson: IEEE Trans. Magn., MAG-14 (1978) 521.

14) D. H. Mosca, F. Petroff, A. Fert, P. A. Schroder, W. P. Pratt Jr and R. Laloee: J. Magn. Magn. Mater., 94 (1994) L1.

15) S. Miura, M. Tsunoda, T. Nagatsuka, S. Sugano and M. Takahashi: J. Appl. Phys., 85 (1999) 4463.

16）高橋 研：まてりあ, 37 (1998) 789.

17) M. Takahashi, S. Miura and M. Tsunoda: Proc. Int. Symp. Nanoscale Magnetism and Transport, Sendai, Japan, 2000, (2000), 130

18）高橋 研, 角田匡清 : 日本応用磁気学会誌, 23 (1999), 1841; M. Takahshi and M. Tsunoda: J. Magn. Magn. Mater, 209 (2000) 65.

19) M. Takahashi, M. Tsunoda and H. Shoji: Vacuum (2000), in press.

20) M. Tsunoda, K. Uneyama, T. Suzuki, K. Yagami and M. Takahashi: J. Appl. Phys., 85 (1999) 4919.

21) E. Fulcomer, S. H. Charap: J. Appl. Phys., 43 (1972) 4190 